\title{
Application of the HBV hydrological model in a flash flood case in Slovenia
}

\author{
M. G. Grillakis, I. K. Tsanis, and A. G. Koutroulis \\ Water Resources Management and Coastal Engineering Laboratory, Environmental Engineering Dept., \\ Technical University of Crete, Greece
}

Received: 19 March 2010 - Revised: 24 November 2010 - Accepted: 25 November 2010 - Published: 22 December 2010

\begin{abstract}
An atmospheric depression passed over northwest Slovenia on 18 September 2007 producing precipitation that exceeded $300 \mathrm{~mm} / \mathrm{d}$ and a 100 -year return period runoff in Zelezniki tributary. The resultant flash flood in the study area, which consisted of five basins, was simulated with the conceptual distributed hydrological model HBV (Hydrologiska Byråns Vattenbalansavdelning). The model was calibrated and validated with past rainfall - runoff events with satisfactory results producing values of Nash - Sutcliffe coefficient between 0.82 and 0.96 . The validated model was applied to the flash flood case with stream gauge failure, driven by spatiotemporal precipitation produced by a set of rain gauges and radar data. The model delivered satisfactory results on three out of five basin outlets while the other two had stream gauge failure during the event. The internal basin dynamics of the most affected area in Zelezniki, was successfully tested in eight of its sub-basins by comparing the peak discharges with the ones evaluated by the slope-conveyance method during a detailed intensive post event campaign. The added value of this method is in the reduced uncertainty in peak discharge estimation and event interpretation and in an effective flash flood warning system for the study area when it is combined with radar nowcasts and operational high resolution short range weather forecast models.
\end{abstract}

\section{Introduction}

Flash floods are one of the most significant natural hazards in Europe, causing serious risk to life and the destruction of buildings and infrastructure (Gaume et al., 2009). Flash floods are those floods that follow the causative storms in a

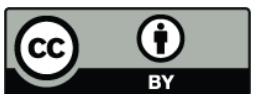

Correspondence to: I. K. Tsanis (tsanis@hydromech.gr) short period of time, with water levels in the drainage network reaching a crest within minutes to a few hours resulting in a very limited opportunity for warnings to be prepared and issued (Borga et al., 2007; Collier, 2007). The rare occurrence of flash floods contributes to a poor understanding of flood processes and large uncertainties, thus, there has been a resurgence on flash flood research (Borrell et al., 2002). Koutroulis and Tsanis (2010) provide a summary of flash flood research using multilateral investigation approaches in order to reduce uncertainty in event interpretations. Mountainous catchment areas represent a great challenge to current flood forecasting models and only allow for short warning periods (Schmitz and Cullmann, 2008) due to their steep slopes and short flow paths, high nonlinearity and pronounced dynamics, as documented in the Zelezniki case study. Montz and Gruntfest (2002) denote that real-time observations with large multi-sensor networks, more precise mapping capabilities using remote sensing and GIS, time efficient hydrological and meteorological models, and increasing forecast lead times have not reduced flood losses. Gruntfest and Handmer (2001) noted that losses will rise in the future, in part, due to climate change, but also because of increases in human activities in flash flood prone areas. Reliable quantitative precipitation forecasts (QPFs) are essential information for flash flood forecasting. A wealth of scientific achievements has been produced in the research areas of radar nowcasting (Germann et al., 2009; Sharif et al., 2006) and operational atmospheric forecasting (Rotach et al., 2009) related to flash flood forecasting. Lin et al. (2005) tested the precipitation forecast skill of four numerical weather prediction models and radar nowcasts based on convectional measures of precipitation forecast skill: probability of detection (POD), false alarm rate (FAR), critical success index (CSI) and conditional mean absolute error (CMAE). They concluded that the radar nowcasts based on Lagrangian advection (Germann and Zawadzki, 2002; Turner et al., 2004)

Published by Copernicus Publications on behalf of the European Geosciences Union. 


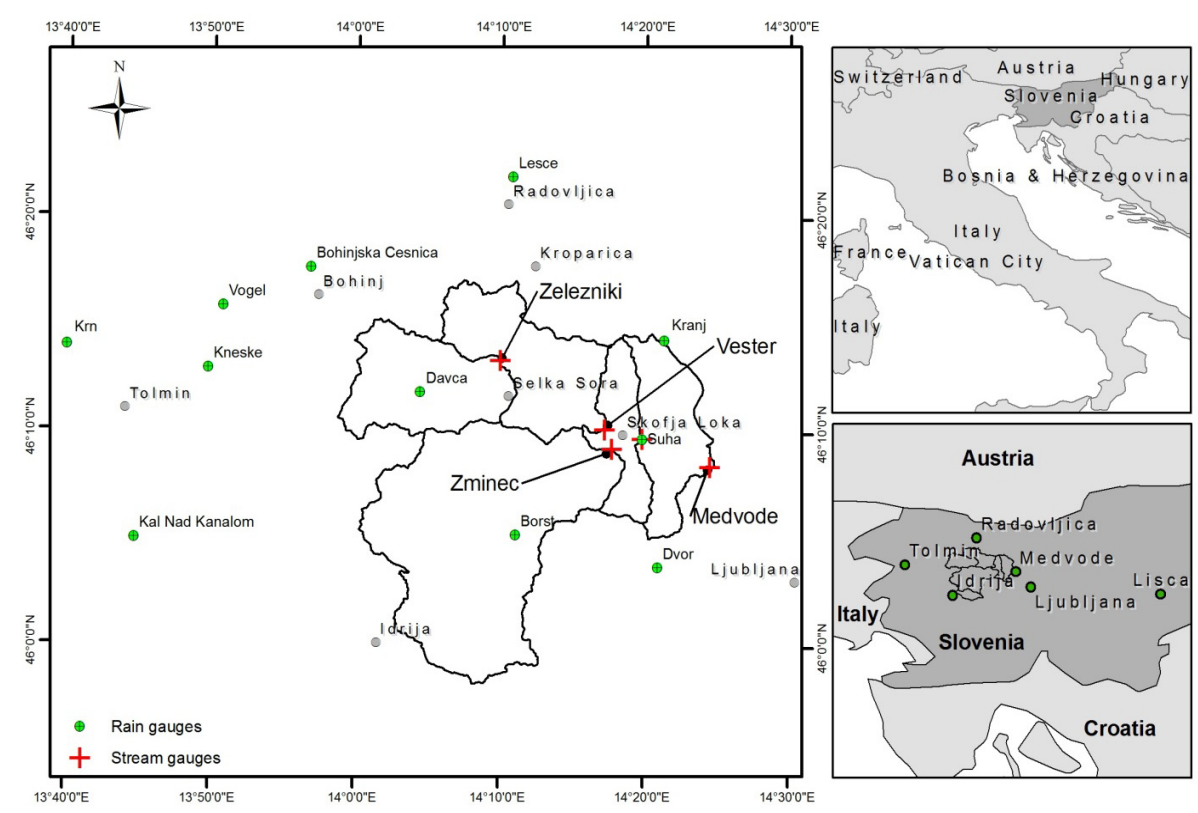

Fig. 1. Case study area divided in five subbasins. Crosses represent the available stream gauges, while cross dots correspond to raingauges used in the present study. Gray dots represent other areas of interest.

better capture the initial precipitation distribution and for lead times up to $6 \mathrm{~h}$, they perform better than weather prediction models. Rainfall runoff modelling is the link between precipitation and a flash flood forecasting system.

On 18 September 2007, an intensive precipitation event over northwest Slovenia triggered a sequence of flash floods in the regions of Baska Grapa, Davca, Cerkljansko and Skofja Loka. Within a few hours precipitation up to $300 \mathrm{~mm}$ was recorded, causing extreme flash flooding in some territories such as Zelezniki (Fig. 1). This area was hit by three flood events during the last 20 years (1990, 1995 and 1998) (Robic, 2008; Rusjan, 2009). From a meteorological perspective, the primary reasons for the extreme precipitation in a very short time were the continuous flow of moist air from the southwest, the strong instability, the wind shear in the lower troposphere and orographic effects (Fig. 2). Although there was a significant skill in forecasting extreme precipitation in Zelezniki 4 days in advance using ECMWF EFI index (EFI - Extreme Forecasting Index, which is an integral measure of the departure between the Ensemble Prediction System forecast and the reference climate distribution) (Strajnar, 2008), unfortunately flooding resulted in seven human casualties (three on Zelezniki) and severe damage on infrastructure and buildings (Fig. 3). The estimated direct economic damage on the streams was 91.5 million Euros (Kobold et al., 2008), while the total estimated indirect damage was 285 million Euros (Bouilloud et al., 2009). In this study, the capability of a parsimonious conceptual rainfall runoff model is examined for flash flood forecasting application in Slovenia Sora river basin. The HBV model is already operational in Northern Austria. The calibration and validation of the model is performed for the entire Sora river basin (Fig. 1), while the internal dynamics of the model are examined in greater detail in the Zelezniki basin where the 2007 catastrophic flood consequences were significant.

\section{Methodology}

\subsection{HBV Model}

The HBV (Hydrologiska Byråns Vattenbalansavdelning) model is a conceptual model of catchment hydrology which simulates discharge using rainfall, temperature and estimates of potential evaporation. HBV is used for flash flood forecasting in northern Austria (Bloschl et al., 2007). The model consists of different routines representing snowmelt by a degree-day method, soil water and evaporation, groundwater described by three linear reservoir equations and channel routing by a triangular weighting function (Seibert, 1997). Descriptions of the model can be found in Bergström (1992, 1995) and Harlin and Kung (1992). The HBV model (Bergström, 1976) has been applied in numerous studies, e.g., to compute hydrological forecasts, for the computation of design floods or for climate change studies. The version of the model used in this study corresponds to the version described by Bloschl et al. (2007). This version of HBV model uses quarter hour time step for precipitation and temperature data while the spatial scale is one kilometre. The model is based on five basic processes through which the rainfall runoff process is simulated. Snowmelt, Soil Moisture Accounting and Hillslope Scale Routing are addressed in the model at pixel scale which is the smallest spatial unit 


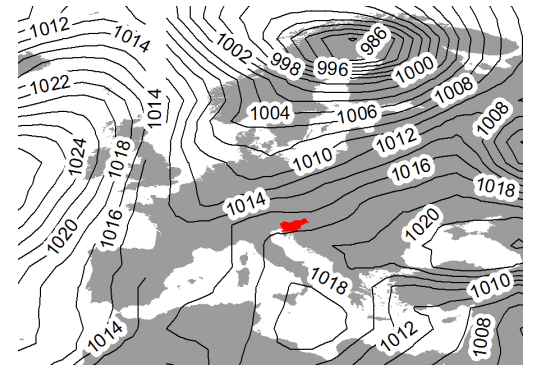

Mean sea level Pressure at 18:00 17/09/2007

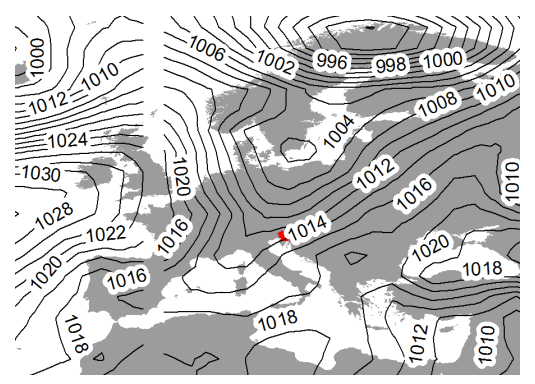

Mean sea level Pressure at 06:00 18/09/2007

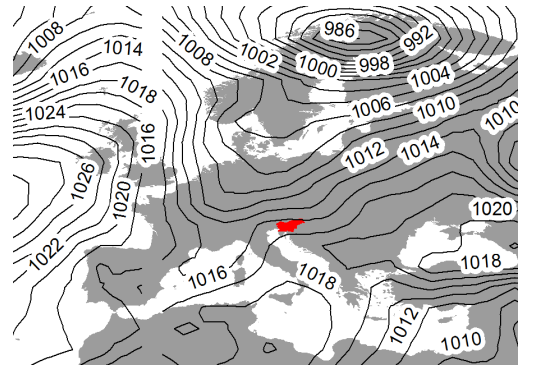

Mean sea level Pressure at 00:00 18/09/2007

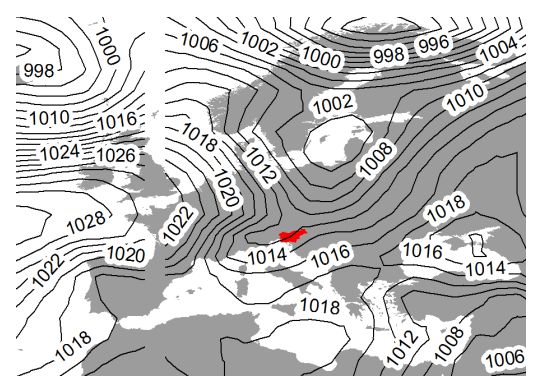

Mean sea level Pressure at 12:00 18/09/2007

Fig. 2. Mean sea-level pressure for 17-18 September 2007 over Europe. The depression over Northern Europe is interpreted clearly at 17/9/2007 18:00, when it moved to central Europe. At 18/9/2007 06:00 it clearly moved southward while at 12:00 it passed over the Slovenia (marked in red).
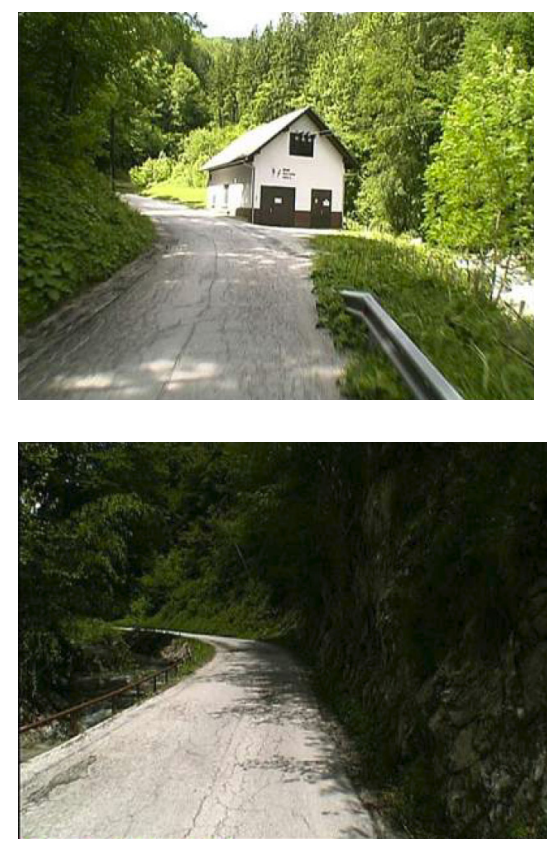

Before the flash flood event
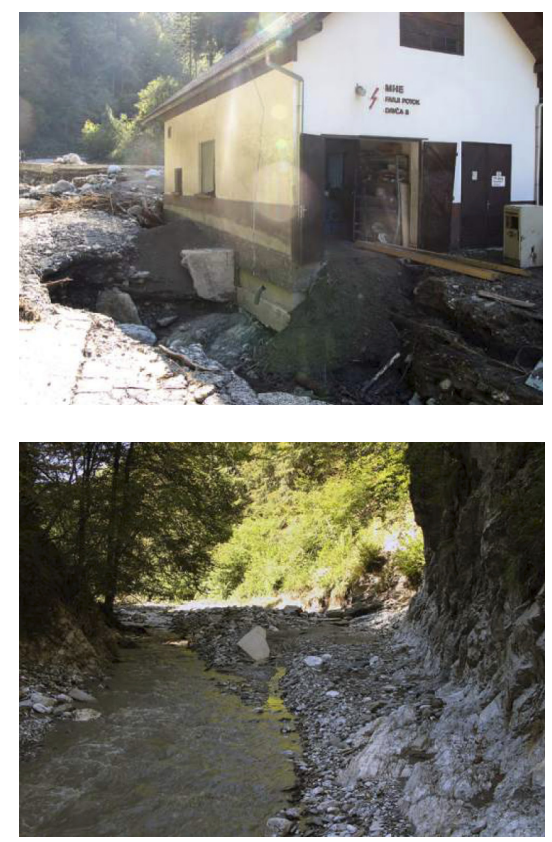

After the flash flood event

Fig. 3. Images presenting the impact of the 2007 flash flood at two locations of Zali Log - Davèa area (source: Environmental Agency of the Republic of Slovenia). 
where the above referred processes take place. The Within Catchment Routing and the Stream Routing processes simulate the runoff process for each catchment and between the catchments, respectively. The snow routine represents snow accumulation and melt by a simple degree-day concept. Soil Moisture Accounting process is calculated as the sum of rainfall and snowmelt, $P_{r}+M$, which splits into a component dS that increases soil moisture of a top layer, $\mathrm{S}_{s}$, and a component $\mathrm{Q}_{p}$ that contributes to runoff. The components are split as a function of $S_{s}$ :

$Q_{p}=\left(\frac{S_{s}}{L_{s}}\right)^{\beta} \cdot\left(P_{r}+M\right)$

where $L_{s}$ is the maximum soil moisture storage and $\beta$ is a nonlinearity parameter (Bergstrom, 1976). The only process that decreases $S_{S}$ is evaporation $E_{A}$ which is calculated from potential evaporation, $E_{P}$, by a piecewise linear function of the soil moisture of the top layer:

$E_{A}=E_{P} \frac{S_{s}}{L_{P}}$ if $S_{S} \prec L_{P}$ otherwise $E_{A}=E_{P}$

where $L_{P}$ is a parameter termed the limit for potential evaporation. Potential evaporation was estimated by the modified Blaney Criddle method (DVWK, 1996) as a function of air temperature. The iterative Eq. (3) summarizes the overall process for each pixel.

$S_{S, i}=S_{S, i-1}+\left(d S-E_{A}\right) \Delta t$

Hillslope scale routing, is represented by three reservoirs. The contribution $Q_{p}$ of rain and snowmelt to runoff entres the upper zone reservoir and leaves this reservoir through two paths: (a) percolation to the lower and groundwater zones, and (b) outflow from the upper zone reservoir. The later outflow from the upper reservoir can occur in two ways, the normal contribution to the outflow, but if a threshold $L_{1}$ of the storage state is exceeded, through a very fast additional outlet. On the Within-catchment routing, the outflow from the reservoirs, $Q_{t}$, is convoluted by a transfer function that represents the runoff routing in the streams within each of the catchments. As a transfer function, a linear storage cascade is used. The convolution is performed in the state space notation (Szolgay, 2004) with discharge dependent parameters. The sum of this convoluted runoff over each direct catchment is used as the lateral inflow to the stream routing model of each river reach. Stream routing processes are formulated directly at the reach scale by making use of a lumped routing model. A linear storage cascade in the state space notation is used with discharge dependent parameters (Szolgay, 2004).

\subsection{Efficiency criteria}

Different efficiency criteria were adopted in order to assess the model delivered results. Efficiency criteria frequently used for hydrological applications and flow comparisons such as Nash-Sutcliffe efficiency and coefficient of determination were used for this study (Krause et al., 2005).
Table 1. Case study area land use according to Corine Land Cover maps of 2000 .

\begin{tabular}{ll}
\hline Land use & Percentage \\
\hline Arable land & 2.29 \\
Forests & 69.11 \\
Heterogeneous agricultural areas & 17.78 \\
Industrial, commercial and transport units & 0.68 \\
Inland waters & 0.03 \\
Pastures & 7.33 \\
Scrub and/or herbaceous vegetation associations & 0.78 \\
Urban fabric & 2.00 \\
\hline
\end{tabular}

\subsubsection{Coefficient of determination $R^{2}$}

The coefficient of determination $R^{2}$ is defined as the squared value of the coefficient of correlation according to BravaisPearson (Rodgers, and Nicewander, 1988). It is calculated as follows with $O$ observed and $P$ predicted values. Bars indicate mean values.

$r^{2}=\left(\frac{\sum_{i=1}^{n}\left(O_{i}-\bar{O}\right)\left(P_{i}-\bar{P}\right)}{\sqrt{\sum_{i=1}^{n}\left(O_{i}-\bar{O}\right)^{2}} \sqrt{\sum_{i=1}^{n}\left(P_{i}-\bar{P}\right)^{2}}}\right)^{2}$

\subsubsection{Nash-Sutcliffe efficiency $E$}

The efficiency $E$ proposed by Nash and Sutcliffe (1970) is defined as one minus the sum of the absolute squared differences between the predicted and observed values normalized by the variance of the observed values during the period under investigation. It is calculated as:

$E=1-\frac{\sum_{i=1}^{n}\left(O_{i}-P_{i}\right)^{2}}{\sum_{i=1}^{n}\left(O_{i}-\bar{O}\right)^{2}}$

where $O$ indicates observed and $P$ predicted values. Bars indicate mean values. The normalization of the variance of the observation series results in relatively higher values of $E$ in catchments with higher dynamics and lower values of $E$ in catchments with lower dynamics. To obtain comparable values of $E$ in a catchment with lower dynamics the prediction has to be better than in a basin with high dynamics. The range of $E$ lies between 1.0 (perfect fit) and $-\infty$. A result lower than zero indicates that the mean value of the observed time series would have been a better predictor than the model. 


\section{Case study}

The case study area terrain is mountainous with steeply rising hills at the western parts. Elevation ranges from $306 \mathrm{~m}$ to $1676 \mathrm{~m}$ with an average of $685 \mathrm{~m}$. At the eastern part of the basin, the slope becomes smoother. The total case study area is $645.7 \mathrm{~km}^{2}$. The main watershed land use as derived from Corine land cover maps is mainly covered by forests $(70.52 \%)$, heterogeneous agricultural areas (18.15\%) and pasture $(7.48 \%)$. Land use types are presented in more detail in Table 1.

\subsection{Model setup}

The Sora basin was delineated at five stream gauging locations resulting in five basins of total area $645.7 \mathrm{~km}^{2}$ (Fig. 1). At the outlet of each basin, discharge data was available for the period $1 / 1 / 2004$ to $31 / 12 / 2007$. The basin outlets were defined at Zelezniki (upstream area $104 \mathrm{~km}^{2}$ ) and Vester $\left(213.8 \mathrm{~km}^{2}\right)$ for the Northern river branch and at Zminec $\left(306.5 \mathrm{~km}^{2}\right)$ for the Southern river branch. The two river branches merge just upstream from Suha $\left(568.9 \mathrm{~km}^{2}\right)$. Finally, the outlet of the modelled area is the discharge gauge of Medvode $\left(645.7 \mathrm{~km}^{2}\right)$. The precipitation data is available for 9 raingauges within or near the study area (Fig. 1) were converted into quarter hour grids of a $1 \mathrm{~km} \times 1 \mathrm{~km}$ grid, according to the spatial resolution of the model. Four routing modules were used to route the discharge between Zelezniki and Vester, Vester and Suha, Zminec and Suha and finally between Suha and Medvode. The model was calibrated for a 40 day period, following a 437 day warming up period. This strategy is essential for the model soil moisture state and discharge initialization, and was also adopted for all the simulation periods.

\subsection{The 18 September 2007 flash flood event analysis}

A pressure depression over Northern Europe on 18 September 2007, moved over the west and middle Europe towards the Alps, with a high valley of cold air moving eastwards over Western Europe (Fig. 2). The system caused strong southwest winds over Slovenia. The convective system was developed above northwest Slovenia, creating precipitation in the early morning between 04:00 CET (Central European Time) and 06:00 CET. After a short pause since 08:00 CET, an intense precipitation event took place due to front extending from Posoèje over Idrija, Cerkljansko and Škofja Loka hills to the northern part of Ljubljana basin. The thunderstorm remained stationary over the basin for nearly two hours. Next, a distinctive stationary thunderstorm line developed at 12:30 CET with a direction from Tolmin to Radovljica. Precipitation weakened at 16:00 CET in Bohinj. New thunderstorm cells formed over Northern Slovenia during the afternoon and precipitation strengthened in the northeast part of Slovenia. Thunderstorms were formed when the
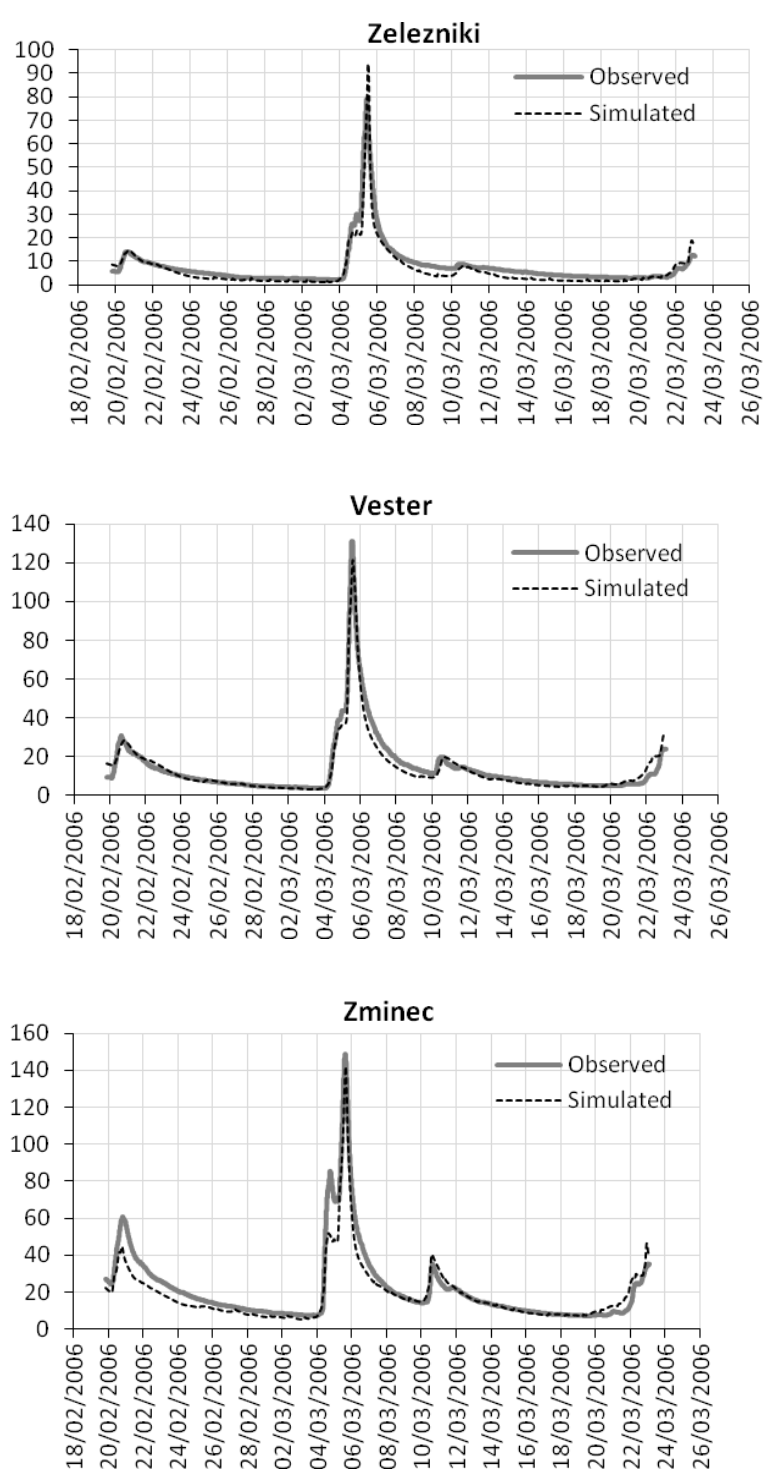

Fig. 4a. Model results for the calibration period, 19/02/2006 to 23/03/2006.

cold front was passing and moved towards the south. Precipitation stopped in the western part of Slovenia around 20:00 CET, in the northwest at midnight, and in the southeast during 01:00 CET and 02:00 CET the next morning.

The operational high-resolution limited area hydrostatic model ALADIN/SI (Aire Limitée Adaptation dynamique Développement InterNational-Limited surface dynamic Adaptation International expansion) was unable to accurately predict the spatial and temporal development of the storm that resulted in an underestimation of the accumulated precipitation by $30 \%$ (Rusjan et al., 2009). Moreover, the local operational radar underestimated the rainfall accumulation by $50 \%$ due to several reasons, analysed by Bouilloud et al. (2009). The main reasons for the underestimation of 
Table 2. Warm up and simulation periods for each subbasin.

\begin{tabular}{llllll}
\hline Subbasin & & $\begin{array}{l}\text { Warming up } \\
\text { start date }\end{array}$ & $\begin{array}{l}\text { Warming up } \\
\text { end date }\end{array}$ & $\begin{array}{l}\text { Simulation } \\
\text { start date }\end{array}$ & $\begin{array}{l}\text { Simulation } \\
\text { end date }\end{array}$ \\
\hline \multirow{2}{*}{ Zelezniki } & Validation & $7 / 7 / 2003$ & $17 / 9 / 2004$ & $17 / 9 / 2004$ & $8 / 11 / 2004$ \\
& Calibration & $9 / 12 / 2004$ & $19 / 2 / 2006$ & $19 / 2 / 2006$ & $23 / 3 / 2006$ \\
\multirow{2}{*}{ Vester } & Validation & $7 / 7 / 2003$ & $17 / 9 / 2004$ & $17 / 9 / 2004$ & $8 / 11 / 2004$ \\
& Calibration & $9 / 12 / 2004$ & $19 / 2 / 2006$ & $19 / 2 / 2006$ & $23 / 3 / 2006$ \\
\multirow{2}{*}{ Zminec } & Validation & $7 / 7 / 2003$ & $17 / 9 / 2004$ & $17 / 9 / 2004$ & $8 / 11 / 2004$ \\
\multirow{2}{*}{ Suha } & Calibration & $9 / 12 / 2004$ & $19 / 2 / 2006$ & $19 / 2 / 2006$ & $23 / 3 / 2006$ \\
\multirow{2}{*}{ Medvode } & Validation & $7 / 7 / 2003$ & $17 / 9 / 2004$ & $17 / 9 / 2004$ & $8 / 11 / 2004$ \\
& Calibration & $9 / 12 / 2004$ & $19 / 2 / 2006$ & $19 / 2 / 2006$ & $23 / 3 / 2006$ \\
& Validation & $7 / 7 / 2003$ & $17 / 9 / 2004$ & $17 / 9 / 2004$ & $8 / 11 / 2004$ \\
\hline
\end{tabular}

Table 3. Coefficient of determination and Nash-Sutcliffe estimators for calibration and validation periods. For Medvode only daily observed data were available.

\begin{tabular}{lllll}
\hline & \multicolumn{2}{c}{ Calibration } & \multicolumn{2}{c}{ Validation } \\
& $R^{2}$ & Nash & $R^{2}$ & Nash \\
\hline Zelezniki & 0.92 & 0.90 & 0.79 & 0.69 \\
Vester & 0.96 & 0.96 & 0.88 & 0.87 \\
Zminec & 0.93 & 0.89 & 0.89 & 0.85 \\
Suha & 0.93 & 0.89 & 0.91 & 0.90 \\
Medvode & 0.86 & 0.82 & 0.58 & 0.47 \\
\hline
\end{tabular}

precipitation were the diversity of terrain, constant inflow of moist air from the southeast, a very unstable atmosphere and wind shear in a higher atmospheric layer (Kobold et al., 2008). The recurrence interval of the recorded precipitation in some areas exceeded 100 years and was even greater for shorter time intervals (ARSO, 2007; Kobold et al., 2008). The observed maximum daily rainfall in Zelezniki (about $200 \mathrm{~mm}$ ) was the highest in the recording period (since 1930) and the maximum daily accumulation was $303 \mathrm{~mm}$, recorded at the Vogel Mountain in NW Slovenia. Hourly accumulated precipitation estimates were up to $150 \mathrm{~mm} / \mathrm{h}$ exceeding a recurrence interval of 200 years (Marchi et al., 2009). Observed peak discharges on the most affected area exceeded existing floods of record values (Kobold et al., 2008). Peak discharge at the Zelezniki gauging station was estimated by the studies of Kobold et al. (2008) and Rusjan et al. (2009) up to $300 \mathrm{~m}^{3} \mathrm{~s}^{-1}$ by extrapolation of the rating curve and up to $278 \mathrm{~m}^{3} \mathrm{~s}^{-1}$ using HEC-1 model, exceeding the 100 -years return period of maximum floods. Peak discharge was also estimated just downstream of Zelezniki to $290 \mathrm{~m}^{3} \mathrm{~s}^{-1} \pm 10 \%$, during a well organized post flash flood survey as described by Marchi et al. (2009), by the slope - conveyance method. The 18 September 2007 catastrophic flash flood event in Slovenia resulted in huge infrastructure and property destruc-
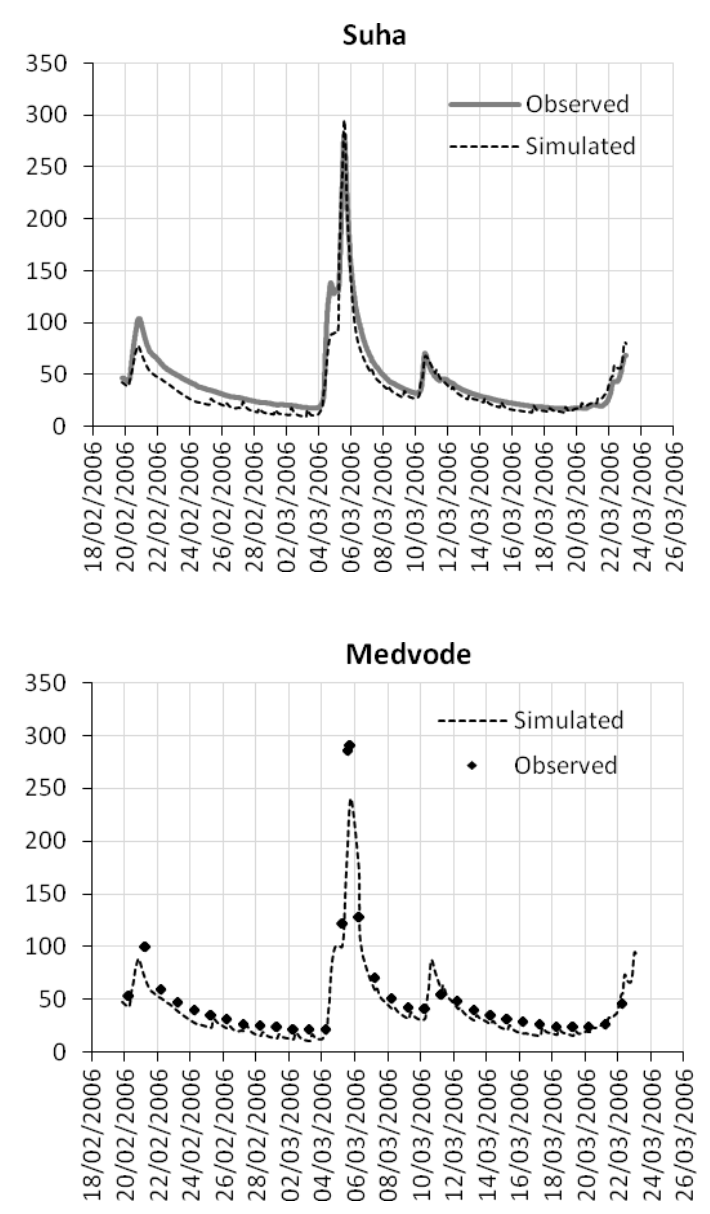

Fig. 4b. Model results for the calibration period, 19/02/2006 to 23/03/2006. Medvode observed hydrograph is plotted with dots due to the daily time resolution. 
Table 4. Site names of IPEC points, IPEC subbasins' areas, HBV model based subbasins' areas, IPEC points estimated and model simulated peak discharges.

\begin{tabular}{|c|c|c|c|c|c|c|c|}
\hline \multirow[b]{2}{*}{ Ref section } & \multirow[b]{2}{*}{ Sora Section } & \multicolumn{3}{|c|}{ Reference section IPEC points } & \multicolumn{3}{|c|}{ HBV simulation } \\
\hline & & $\begin{array}{c}\text { Watershed } \\
\text { area } \\
{\left[\mathrm{km}^{2}\right]}\end{array}$ & $\begin{array}{c}\text { Estimated Peak } \\
\text { Discharge } \\
{\left[\mathrm{m}^{3} \mathrm{~s}^{-1}\right]}\end{array}$ & $\begin{array}{c}\text { Unit peak } \\
\text { discharge } \\
{\left[\mathrm{m}^{3} \mathrm{~s}^{-1} \mathrm{~km}^{-2}\right]}\end{array}$ & $\begin{array}{c}\text { HBV watershed } \\
\text { area } \\
{\left[\mathrm{km}^{2}\right]}\end{array}$ & $\begin{array}{c}\text { Modelled Peak } \\
\text { Discharge } \\
{\left[\mathrm{m}^{3} \mathrm{~s}^{-1}\right]}\end{array}$ & $\begin{array}{c}\text { Unit peak } \\
\text { discharge } \\
{\left[\mathrm{m}^{3} \mathrm{~s}^{-1} \mathrm{~km}^{-2}\right]}\end{array}$ \\
\hline 1 & Downstream Zadnja Sora inflow & 9 & $50-70$ & $5.6-7.8$ & 10 & 53.76 & 5.38 \\
\hline 2 & Downstream Globoka inflow & 24.7 & $85-125$ & $3.4-5.1$ & 25 & 109.18 & 4.37 \\
\hline 3 & Downstream Danjarska grapa inflow & 40.7 & $125-155$ & $3.1-3.8$ & 40 & 160.6 & 4.02 \\
\hline 4 & Upstream Zali Log & 44.8 & $140-200$ & $3.1-4.5$ & 45 & 179.88 & 4.00 \\
\hline 5 & Between Zali Log and Davca inflow & 46.8 & $170-230$ & $3.6-4.9$ & 48 & 192.06 & 4.00 \\
\hline 6 & Upstream Zadnja Smoleva inflow & 80.4 & $290-350$ & $3.6-4.4$ & 81 & 283.34 & 3.50 \\
\hline 7 & Upstream Prednja Smoleva inflow & 95.5 & $330-430$ & $3.5-4.5$ & 97 & 325.42 & 3.35 \\
\hline 8 & Zelezniki HBV outlet & 103.9 & - & - & 104 & 346.33 & 3.33 \\
\hline
\end{tabular}

Table 5. Gauges with available data, type of records and time-step.

\begin{tabular}{lll}
\hline Gauge Name & Type of data recorded & Time step \\
\hline Polj Sira Zminec & Discharge & Hourly \\
Sel Sora Vester & Discharge & Hourly \\
Sel Sora Zelezniki & Discharge & Hourly \\
Sora Medvode & Discharge & Daily \\
Sora Suha & Discharge & Hourly \\
Bohinjska Cesnica & Temperature & Hourly \\
Kranj REG & Temperature & Hourly \\
Krn REG & Temperature & Hourly \\
Vogel REG & Temperature & Hourly \\
Borst AMP & Temperature & Hourly \\
Vogel & Rainfall & Hourly \\
Bohinjska Cesnica & Rainfall & Hourly \\
Borst AMP & Rainfall & Hourly \\
Davca & Rainfall & Hourly \\
Dvor AMP & Rainfall & Hourly \\
Kal Nad Kanalom & Rainfall & Hourly \\
Knezke ravne & Rainfall & Hourly \\
Lesce & Rainfall & Hourly \\
Suha AMP & Rainfall & Hourly \\
\hline
\end{tabular}

tion in the densely populated valleys of Selska Sora, Davca and Kroparica (Figs. 1 and 3) and the loss of seven lives.

\subsection{Data availability}

For the HBV model setup and calibration, hydrologic and geomorphologic data were provided by Environmental Agency of Slovenia - ARSO (Agencija Republike Slovenije za Okolje). Stream gauge measurements were available for the period $1 / 1 / 2004$ to $31 / 12 / 2007$. Rainfall and temperature data are available for 9 and 5 gauges, respectively, for the $1 / 1 / 2003$ to $31 / 12 / 2007$ period (Table 2). Spatial data for land use (Corine Land Cover maps, 2000), geology and elevation (DTM) were used to complete the setup tasks. For the flash flood event on 18 September 2007, the stream gauges failed at Zelezniki and Suha. Calibrated radar precipitation data for the flash flood event were available from Liska Cband radar, located $100 \mathrm{~km}$ away to the East of the study area (Bouilloud et al., 2009).

An intensive post-event campaign was organized two months after the flash flood event, documenting valuable information and estimates of peak discharge for 22 locations upstream in the most affected area of Zelezniki (Marchi et al., 2009). The peak discharges were estimated using the slope-conveyance method (Gaume, 2006).

Various discharge estimation methods, also called indirect discharge measurement methods, have been developed in the past (Webb and Jarrett, 2002; Benson and Dalrymple, 1967), to homogenize the procedures used and to share the experience gained by the hydrological community. Experience summarized in empirical formulas to compute the ManningStrickler roughness coefficient. After a major revision of these methods, Gaume (2006) concludes that, all in all, estimating peak discharges when no direct current-metre measurement is available is, above all, a question of sound engineering judgment and experience. Empirical relations must be used with caution, as guidelines, and their systematic use may have, in the past, led to systematic over-estimations of the largest flash-floods (Jarrett, 1987). A corollary to this conclusion is that large efforts must also be put on the critics of the estimated values during the field investigation.

Therefore, for the present study, discharges were estimated for a minimum of two or three cross-sections for the same river reach in order to reduce uncertainties. Moreover, the cross-sectional flow area may vary significantly between sections, and a discharge estimate made for one section may imply an unrealistic velocity value for another section and, consequently, be rejected. Uncertainties during the present IPEC (Intensive Post Event Campain) examined by testing the upstream-downstream coherence of the estimates and their coherence with the rainfall data. However, the accuracy of the peak discharge estimates remains highly dependent 

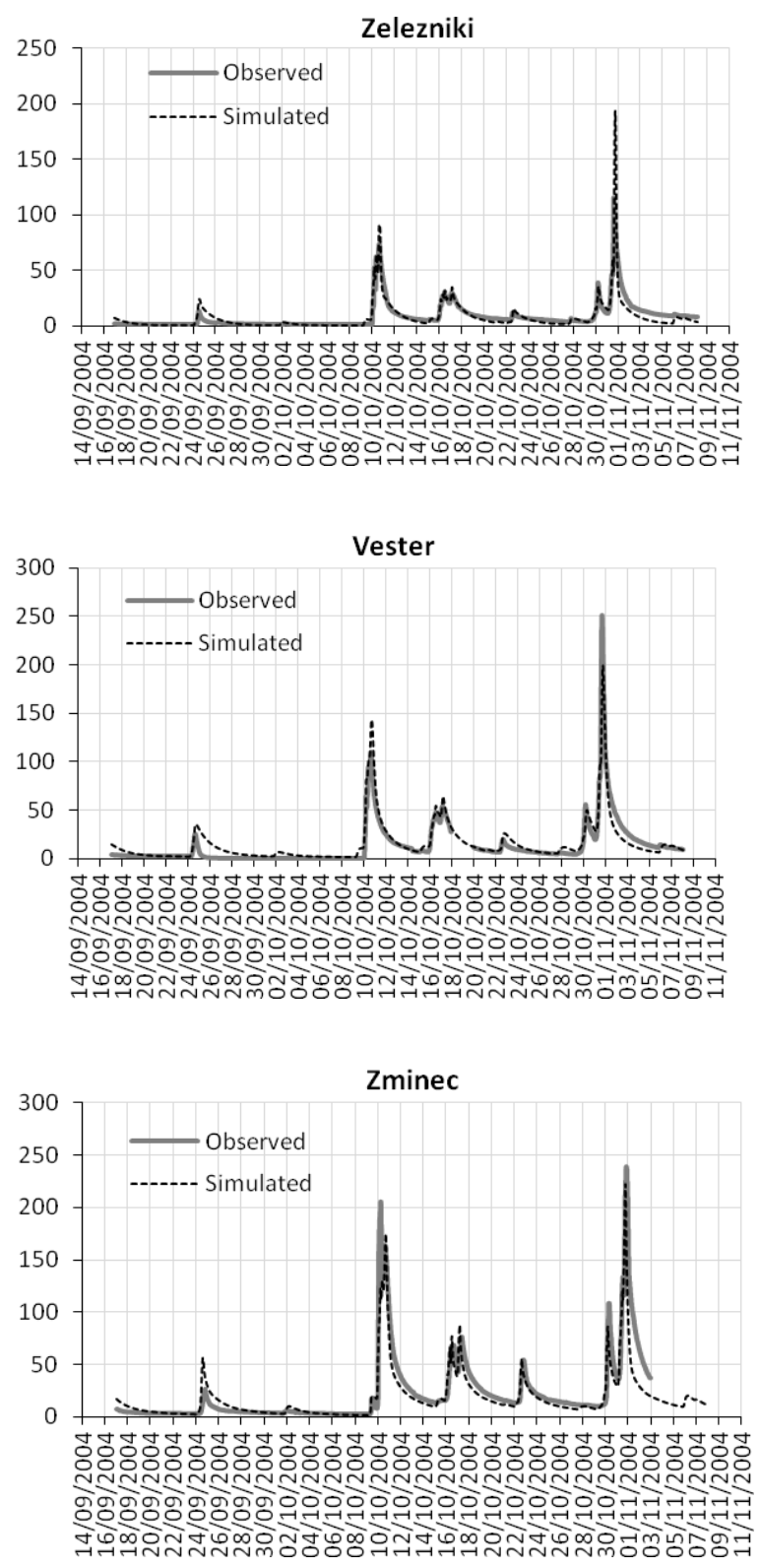

Fig. 5a. Model results for the validation period, 17/09/2004 to 08/11/2004.

on the experience of the expert. Experienced hydrologists from many European countries joined this common IPEC provided valuable knowledge, estimating uncertainty in peak discharge estimation ranging from $\pm 10 \%$ to $\pm 25 \%$. This, "optimistic" low uncertainty estimates are mainly due to upstream-downstream coherence of the estimates their coherence with the rainfall data, the sensitivity of the estimates on multiple Manning roughness coefficients and expert judgment.
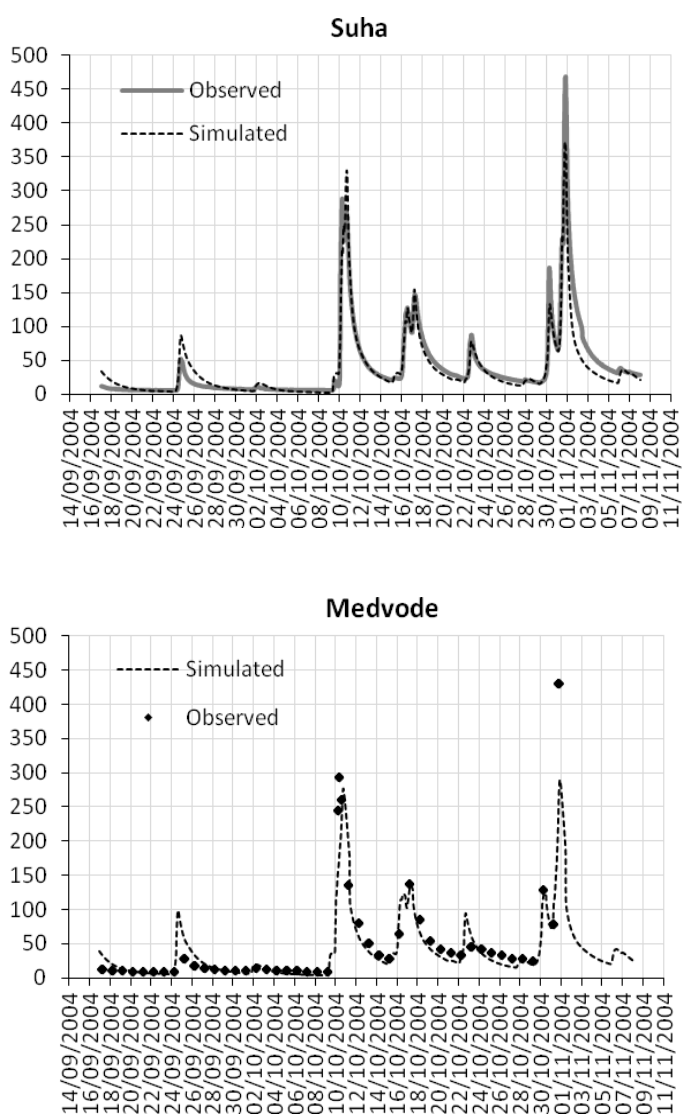

Fig. 5b. Model results for the validation period, 17/09/2004 to $08 / 11 / 2004$. Medvode observed hydrograph is plotted with dots due to the daily time resolution.

\section{HBV model calibration and validation}

Geological and land use data were used to identify model parameters. Hydrological response units (HRUs) were derived from terrain slope and geology classification into different percolation classes and land use characterisation in major land use categories. However, the map overlay approach does not follow the procedure for HRU identification as described by Bloschl et al. (2007), who defined HRUs manually allowing some interpretation of the area's hydrology to be introduced. Hence, model parameters were adjusted during model calibration.

Three extended periods were selected in order to calibrate the parameters of the model and evaluate its efficiency. All three periods were selected using the high discharge criterion (peak discharge occurrence greater than $250 \mathrm{~m}^{3} \mathrm{~s}^{-1}$ ) on Medvode flow station. The model was used for long-term (continuous) simulation so the calibration and the validation periods included several single - high flow - events. Each period is separated in two parts. The first part lasts for 42000 of 15 min time steps or 437.5 days. The objective of this period is the model warm up. The following (second) period lasts 

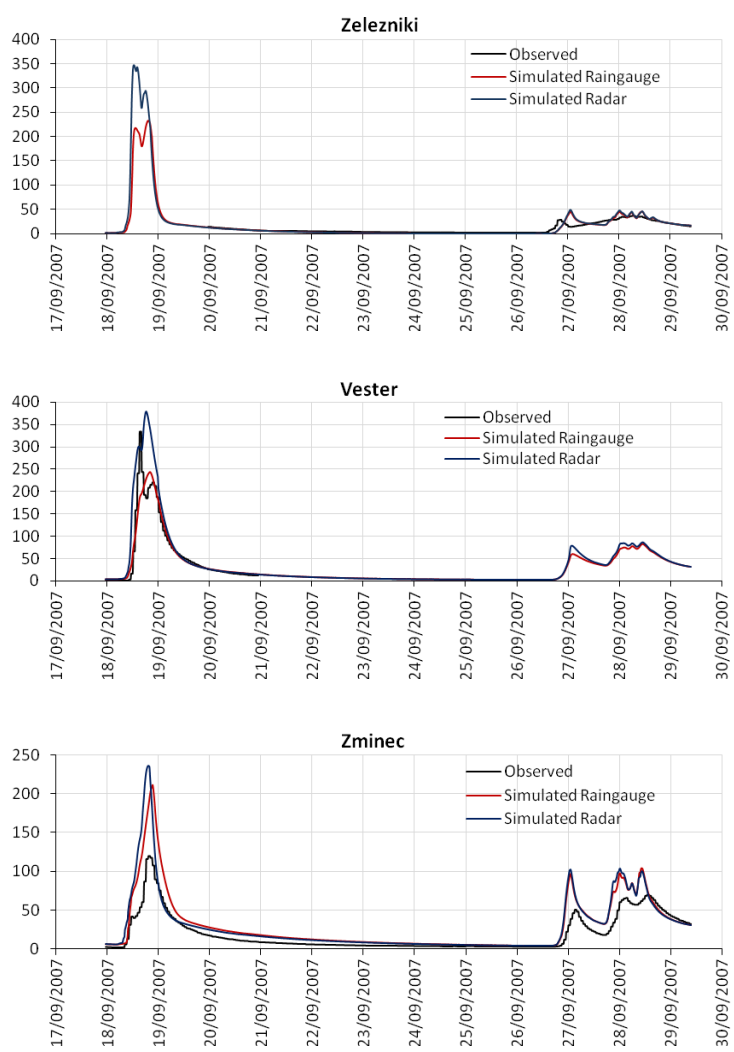

Fig. 6a. Model results for the flash flood period of 18 September 2007 using interpolated raingauge precipitation.
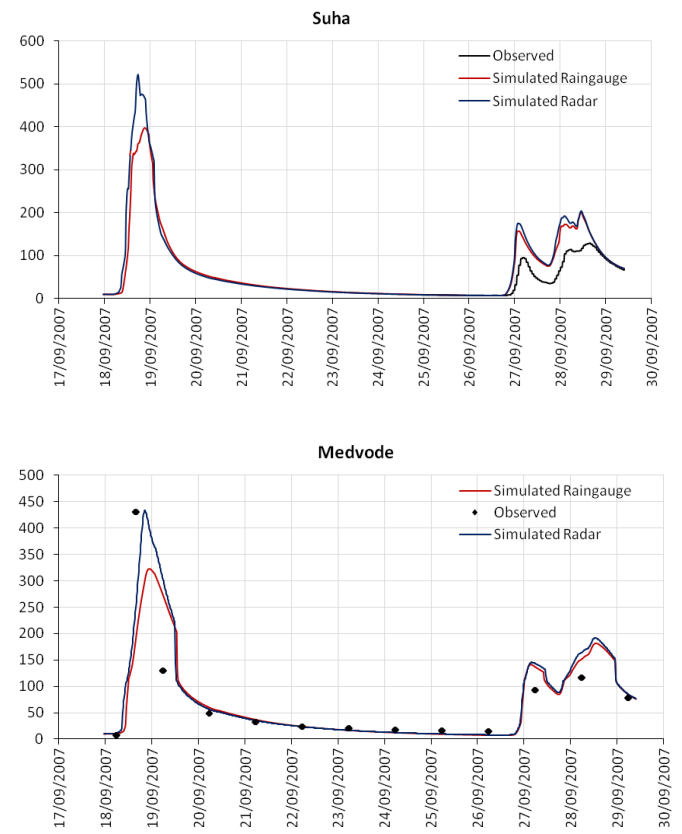

Fig. 6b. Model results for the flash flood period of 18 September 2007 using interpolated raingauge precipitation. Medvode observed hydrograph is plotted with dots due to the daily time resolution. for 3000 to 5000 time steps (up to 52 days) and corresponds to the period where high outflows were recorded at Suha and Medvode stations. Before every warm up run, HBV model was initialized with $50 \%$ soil moisture saturation for each grid cell. The initial soil moisture value does not really affect the simulation results because the initial value is adjusted in the warming up period, but the standard value $50 \%$ was used in order to deliver unbiased initial model conditions for all simulations. Table 3 presents the warming up and simulation periods. In Figs. $4 \mathrm{a}, \mathrm{b}, 5 \mathrm{a}$ and $\mathrm{b}$ the produced hydrographs are presented for all five basins. The efficiency of the model was derived based on the estimators presented in Sect. 2.2. Table 4 presents the $R^{2}$ and $E$ values for the model simulations for calibration and validation results for all five basins. The model Nash values varied between 0.82 and 0.96 on the calibration period for all basins. For the validation period, Nash varied between 0.47 and 0.90 . Similar results were obtained for the coefficient of determination $R^{2}$, which varied between 0.86 and 0.96 for the calibration period and 0.58 to 0.91 for the validation period. An important factor of the poor model estimations on Medvode basin is the temporal scale of observed discharge data, which were available on daily time intervals. Hence, Suha outlet can better describe the model setup performance. Overall, model describes the runoff dynamics very well, as shown in Figs. 4a, b, 5a and b.

\section{Results and discussion}

The calibrated model was applied to the flash flood event of 18 September (Figs. 6a and b). Available precipitation data from Lisca C-band radar were also tested for the flash flood event in addition to the raingauge interpolated data. Using the raingauge data, the peak discharge on Vester was underestimated comparing to the observed peak flow by $27 \%$ from $244.3 \mathrm{~m}^{3} \mathrm{~s}^{-1}$ to $334.6 \mathrm{~m}^{3} \mathrm{~s}^{-1}$ for observed and simulated discharge, respectively. Using the radar data, the peak discharge was overestimated against the observed data by $13.4 \%$ to $380 \mathrm{~m}^{3} \mathrm{~s}^{-1}$. On Zminec basin both raingauge and radar data overestimated the observed $120 \mathrm{~m}^{3} \mathrm{~s}^{-1}$ to $211.4 \mathrm{~m}^{3} \mathrm{~s}^{-1}$ and $235.8 \mathrm{~m}^{3} \mathrm{~s}^{-1}$, respectively. For Suha, no observed discharge was recorded during the flash flood event due to stream gauge failure. The Medvode observed peak discharge was underestimated by the model using raingauge interpolated data by $25 \%$, from $429.8 \mathrm{~m}^{3} \mathrm{~s}^{-1}$ to $322.8 \mathrm{~m}^{3} \mathrm{~s}^{-1}$ in observed and simulated peak discharges, respectively. The radar precipitation delivered peak flow was $433 \mathrm{~m}^{3} \mathrm{~s}^{-1}$, thus, simulated the peak discharge at the outlet very well. It should be noted that the observed value on Medvode refers to one single measurement, because the stage gauge is not automatic. The Zelezniki basin results are further discussed in detail, in order to examine the internal model runoff dynamics in combination with surveyed high-water marks. 

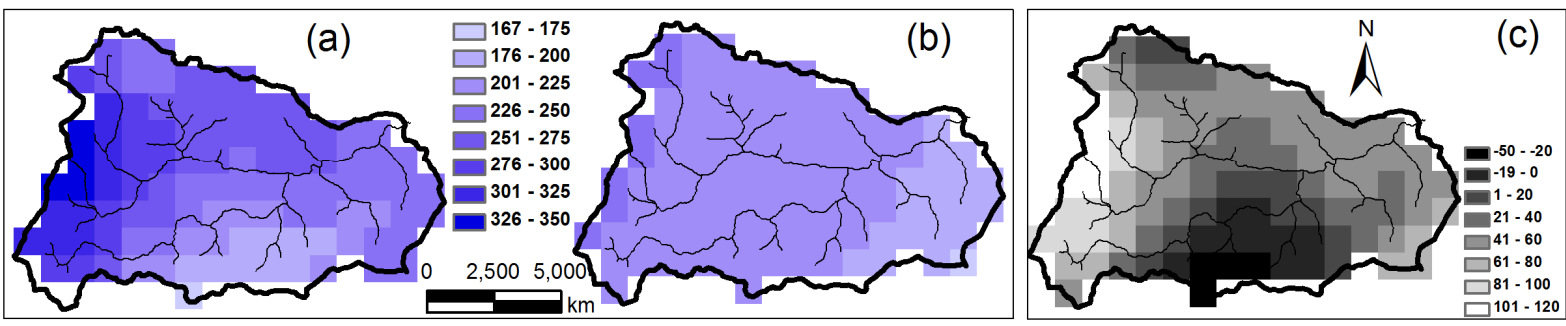

Fig. 7. Storm total rainfall $(\mathrm{mm})$ for 18 September 2007 flood based on (a) radar observations, (b) interpolated raingauge measurements with a spatial resolution of $1 \mathrm{~km}$ and (c) is the difference among (a) and (b) estimates.

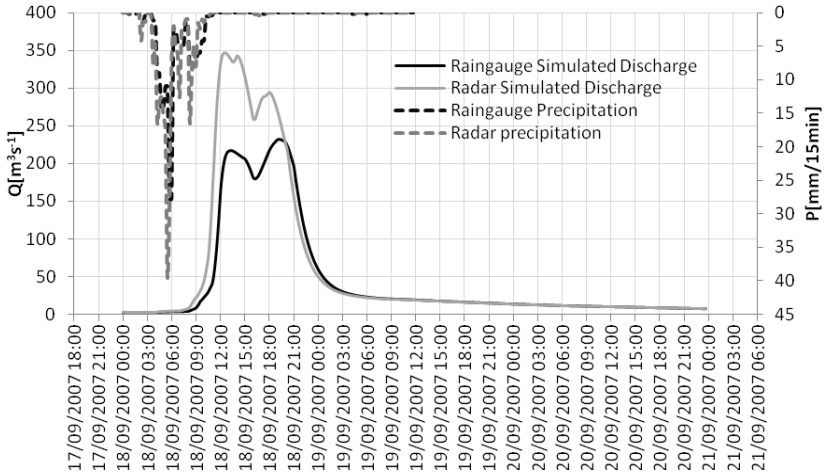

Fig. 8. Calibrated radar and raingauge interpolated precipitation simulated hydrographs for Zelezniki subbasin for the flash flood event on 18 September 2007.

\subsection{Zelezniki subbasin 18 September analysis}

The flash flood event of 18 September 2007, caused failure to the stream gauges of Zelezniki and Suha stations. In the most affected area of Zelezniki, radar calibrated precipitation was tested against the raingauge interpolated precipitation. Figure 7 presents the two different estimates of storm total rainfall for the 18 September 2007 flood based on radar observations and interpolated raingauge measurements with a spatial resolution of $1 \mathrm{~km}$. The radar precipitation observations were available from Liska C-band radar located about $100 \mathrm{~km}$ to the East of Zelezniki and were calibrated based on 47 hourly raingauges using the Mountain Reference Technique (MRT) (Bouilloud et al., 2009). The storm total precipitation depth over the Zelezniki basin was estimated at $214.8 \mathrm{~mm}$ from the raingauge interpolated data for the 18th of September. The corresponding total precipitation from the radar data was about $17 \%$ higher at $252 \mathrm{~mm}$. Furthermore, the two precipitation time series show different peak times and maximum intensities with the radar data showing a maximum 30-min intensity of $39.9 \mathrm{~mm}$ between 10:30 CET to 11:00 CET and rain gauge interpolated rainfall data showing maximum $30 \mathrm{~min}$ intensity of $27.8 \mathrm{~mm}$ between 11:00 CET and 12:00 CET.
Rainfall-runoff simulation resulted in a double peak hydrograph. The raingauge precipitation delivered two peaks of $216.9 \mathrm{~m}^{3} \mathrm{~s}^{-1}$ and $231.9 \mathrm{~m}^{3} \mathrm{~s}^{-1}$ at 13:15 CET and 19:15 CET, respectively, while for the radar precipitation the simulated peaks were $346.4 \mathrm{~m}^{3} \mathrm{~s}^{-1}$ and $293.9 \mathrm{~m}^{3} \mathrm{~s}^{-1}$ at 12:30 CET and 18:00 CET, respectively. The radar precipitation simulation agrees with the eyewitness delivered peak time of the flood at 12:30 CET, while the second peak time agrees with previous simulation by Marchi et al. (2009). The simulation of radar precipitation peak at 12:30 CET overestimated the raingauge simulation peak at $13: 15$ CET by $37.4 \%$ and the raingauge simulation peak at 19:15 CET by $33 \%$. Figure 8 presents the two different flow hydrographs. Information collected by means of eyewitness interviews (Marchi et al., 2009) and high-water marks resulted to reliable reconstruction of the time evolution, the magnitude and the flow process of the flood. Marchi et al. (2009) concluded an approximately $300 \mathrm{~m}^{3} \mathrm{~s}^{-1}$ peak discharge at 12:30 CET. Similar results were obtained from Kobold et al. (2008).

A detailed hydrological analysis of the event performed by Zanon et al. (2010) through a high resolution distributed rainfall runoff model, derived peak discharge within a range from $312 \mathrm{~m}^{3} \mathrm{~s}^{-1}$ to $350 \mathrm{~m}^{3} \mathrm{~s}^{-1}$, based on spatially averaged and spatially distributes rainfall rates, at 12:30 CET. The comparison of HBV model results based on radar precipitation data with the previously estimates shows a fairly good agreement in the timing and the magnitude of the flood. Runoff results based on raingauge data presents a significant underestimation of the peak flow and the timing of the event. The HBV simulated total runoff volume based on radar data is higher by $30 \%$ than the corresponding one based on gauged data, due to higher intensity occurring in shorter time period and higher total precipitation volume. This produces an increase of the total discharge volume, increasing the runoff coefficient from 0.44 to 0.49 . The simulated peak discharges were translated to specific peak discharges at $2.23 \mathrm{~m}^{3} \mathrm{~s}^{-1} \mathrm{~km}^{-2}$ and $3.35 \mathrm{~m}^{3} \mathrm{~s}^{-1} \mathrm{~km}^{-2}$, respectively.

To investigate the ability of the model in capturing the internal watershed dynamics, the Zelezniki subbasin was divided into 8 subbasins. The model spatial resolution was kept at $1 \mathrm{~km}$ grid size in order to keep the model dynamics consistent to the single basin setup. The model results 


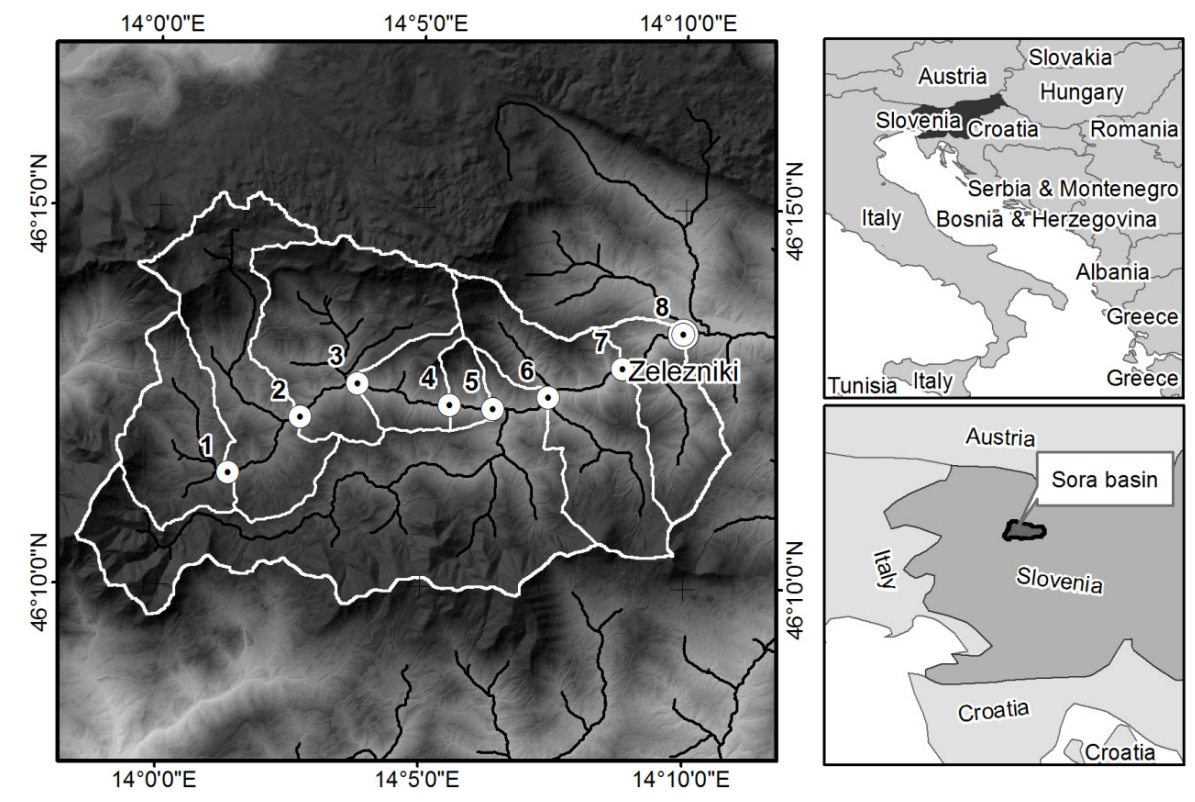

Fig. 9. The seven IPEC locations (1-7) where the peak discharges were estimated from high-water marks and compared to the simulated discharges, and the Zelezniki outlet (8).

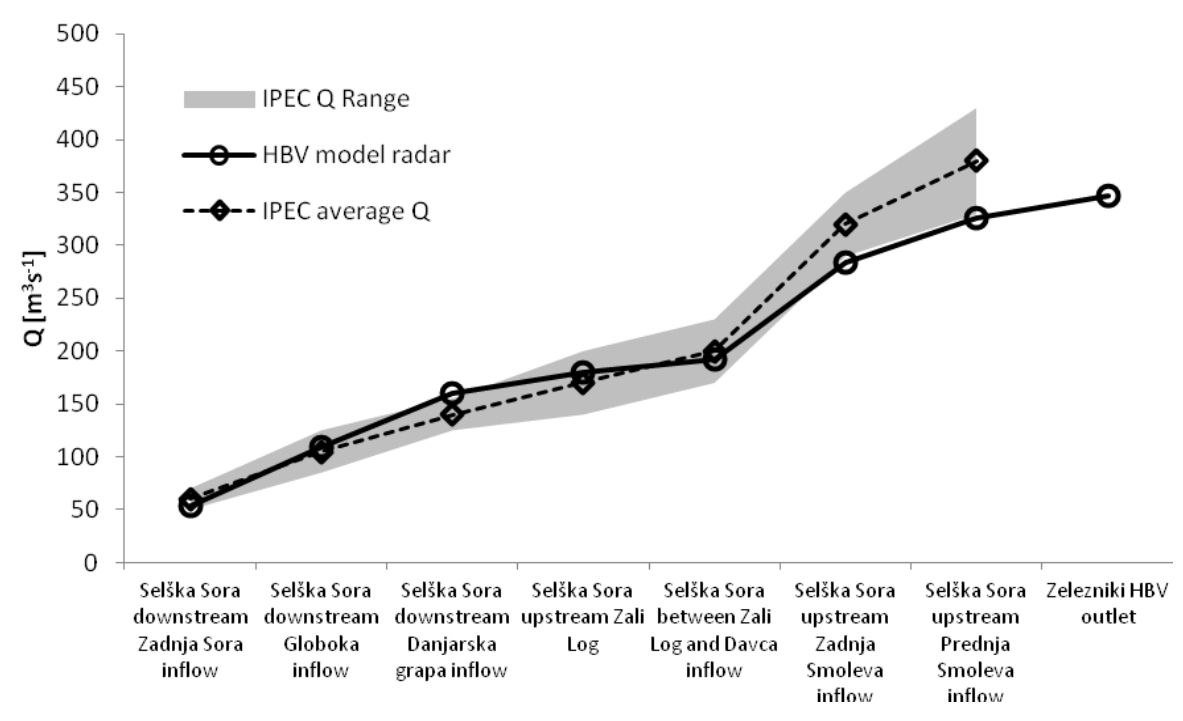

Fig. 10. Modelled vs IPEC estimated peak discharges. Dash line is the survey estimated peak discharge and the solid line is the modelled peak discharge. The gray area represents the uncertainty range of IPEC peak discharge estimations.

using the calibrated radar precipitation were compared to the peak discharge computed with the slope-conveyance method (Zanon et al., 2010) as they occurred by a detailed intensive post event campaign (IPEC), upstream from Zelezniki. Peak discharge data from seven locations were compared to the modelled peak discharge (Fig. 9). Table 5 presents the contributing basin area to each IPEC point - outlet, the discharge estimated by the slope-conveyance method within an uncer- tainty range, the contributing area based on HBV setup, the HBV simulated peak discharge at each IPEC point and the unit peak discharges estimated from the IPEC and the HBV simulation. Minor differences in the model used and the actual surveyed watershed area for each one of the seven IPEC points occurred due to the coarse model spatial scale. The comparison among the IPEC estimation and the modelled results is clearly shown in Fig. 10, where both the former 
results are presented for each point of interest. The correlation between the average IPEC discharge estimations and the simulated peak discharges delivered $R^{2}$ value of 0.98 . The simulated results are within the range of IPEC results with only the Selška Sora downstream from the Danjarska grapa section being slightly out of the IPEC range. The coarse spatial resolution distributed rainfall-runoff model, $\mathrm{HBV}$, can adequately represent flash flood hydrograph and internal basin dynamics.

\section{Conclusions}

The aim of the study is to present the capability of a parsimonious conceptual rainfall runoff model to describe the internal basin dynamics of flash flood events and eventually the capability for flash flood forecasting applications. The simulated results give a very good perspective of the model in the case study basin simulations. The overall model performance for the calibration and validation period was very good. For the flash flood event, even while the observed data were not sufficient to evaluate the model, the results were representative. This is fully consistent with the raingauge available data, consisted of three raingauges within the $645.7 \mathrm{~km}^{2}$ size basin that cannot capture in detail the spatial variability of the precipitation depth and the spatial intensity associated with the flash flood event. In addition, calibrated radar precipitation that was tested, showed better performance in some cases such as Zelezniki and Vester basins. The closer examination of the Zelezniki subcatchment show a very good performance of the model in terms of peak discharge, watershed response time and internal watershed dynamics. Data provided for this work come from three installed rain gauges inside the case study watershed and six external rain gauges. A denser rain gauge network could deliver more accurate precipitation grids and a better simulation due to precipitation over/under-estimation avoidance. Real-time calibrated radar data could improve the representation of precipitation distribution combined with the point measurements. Finally, it is important to utilize a combination of information from intensive post event surveys with rainfall-runoff modelling that will decrease the uncertainty in peak discharge estimation and event interpretation. As a consequence, the concept of parsimony in rainfall runoff modelling can be applied towards a low computational demand-effective flash flood warning system for the study area, when combined with operational radar nowcasts or high resolution weather forecast models.

Acknowledgements. The European Commission's Sixth Framework Programme supported this work through the grant to the Project HYDRATE, Contract GOCE 037024. The Environmental Agency of Slovenia (ARSO) is gratefully acknowledged for the availability of the data used on this work and especially Nejc Poganèik for his exclusive assistance on data processing. The authors are grateful to G. Blöschl and J. Komma for providing the HBV model and their generous support and wish to thank M. Borga and F. Zanon for their valuable comments and suggestions. L. Bouilloud is thankfully acknowledged for providing the calibrated radar data used in this study.

Edited by: F. Castelli

Reviewed by: R. Jarrett and another anonymous referee

\section{References}

ARSO: Izjemen padavinski dogodek 18. Septembra 2007 (Extreme rainfall event on 18.9.2007-in Slovenian), Environmental Agency of the Republic of Slovenia, Ljubljana, http://www.arso.gov.si/vreme/poro\%c4\%8dila\%20in\% 20projekti/padavine_18sep07.pdf,2007.

Benson, M. A. and Dalrymple, T.: General field and office procedures for indirect discharge measurements, Tech. Water-Resour. Invest. (U.S. Geol. Surv.), Book 3, Ch. A1, 1-30, 1967.

Bergström, S.: Development and application of a conceptual runoff model for Scandinavian catchments. SMHI Reports RHO, No. 7, Norrköping, 1976.

Bergström, S.: The HBV model - its structure and applications. SMHI Reports RH, No. 4, Norrköping, 1992.

Bloschl, G., Reszler, C., and Komma, J.: A spatially distributed flash flood forecasting model, Environ. Modell. Software, 23, 464-478, 2007.

Borga, M., Boscolo, P., Zanon, F., and Sangati, M.: Hydrometeorological analysis of the August 29, 2003 flash flood in the eastern Italian Alps, J. Hydrometeorol., 8(3), 1049-1067, doi:10.1175/JHM593.1., 2007.

Borrell, V. E., Llovel, C., and Dartus, D.: Flash flood forecast hydrological model. Development and application of computer techniques to environmental studies, 449-458, 2002. ISBN:185312-909-7, 2002.

Bouilloud, L., Delrieu, G., Boudevillain, B., Borga, M., and Zanon, F.: Radar rainfall estimation for the post-event analysis of a Slovenian flash-flood case: application of the Mountain Reference Technique at C-band frequency, Hydrol. Earth Syst. Sci., 13, 1349-1360, doi:10.5194/hess-13-1349-2009, 2009.

Collier, C. G.: Flash flood forecasting: What are the limits of predictability?, Q. J. Roy. Meteor. Soc., 133(622), 3-23, doi:10.1002/qj.29., 2007.

DVWK (German Association for Water, Wastewater and Waste): Ermittlung der Verdunstung von Land- und Wasserflächen Heft 238, DVWK-Merkblätter, Bonn, 1996 (in German).

Gaume, E.: Post flash-flood investigation - methodological note, Floodsite European Research Project, Report number T23-0602, Revision Number 1_0_P01, http://www.floodsite.net/, 2006.

Gaume, E., Bain, V., Bernardara, P., Newinger, O., Barbuc, M., Bateman, A., Blaškovièová, L., Blöschl, G., Borga, M., Dumitrescu, A., Daliakopoulos, I., Garcia, J., Irimescu, A., Kohnova, S., Koutroulis, A., Marchi, L., Matreata, S., Medina, V., Preciso, E., Sempere-Torres, D., Stancalie, G., Szolgay, J., Tsanis, I., Velasco, D., and Viglione, A.: A compilation of data on European flash floods, J. Hydrol., 367, 70-78, doi:10.1016/j.jhydrol.2008.12.028., 2009.

Germann, U. and Zawadzki, I.: Scale dependence of the predictability of precipitation from continental radar images. Part 
I: description of the methodology, Mon. Weather Rev. 130(12), 2859-2873, 2002.

Germann, U., Berenguer, M., Sempere-Torres, D., and Zappa, M.: REAL-Ensemble radar precipitation estimation for hydrology in a mountainous region, Q. J. R. Meteorol. Soc., 135(639), http: //dx.doi.org/10.1002/qj.375, 2009.

Gruntfest, E. and Handmer, J.: Dealing with flash floods: contemporary issues and future possibilities. in: Coping with Flash Floods, edited by: Gruntfest, E. and Handmer, J., Kluwer Academic Publishers, Dordrecht, 3-10, 2001.

Harlin, J. and Kung, C. S.: Parameter uncertainty and simulation of design floods in Sweden, J. Hydrol., 137, 209-230, 1992.

Jarrett, R. D.: Errors in slope-area computations of peak discharges in mountain streams, J. Hydrol., 96, 53-67, 1987.

Kobold, M. and Brilly, M.: The use of HBV model for flash flood forecasting, Nat. Hazards Earth Syst. Sci., 6, 407-417, doi:10.5194/nhess-6-407-2006, 2006.

Kobold, M., Sušnik, M., Robiè, M., Ulaga, F., and Laliæ, B.: Hydrological analysis of high waters and flash floods occurred in September 2007 in Slovenia, Earth Environ. Sci., 4, 012008, doi:10.1088/1755-1307/4/1/012008, 2008.

Koutroulis, A. G. and Tsanis, I. K.: A method for estimating flash flood peak discharge in a poorly gauged basin: Case study for the 13-14 January 1994 flood, Giofiros basin, Crete, Greece, J. Hydrol., 385, 150-164, doi:10.1016/j.jhydrol.2010.02.012, 2010.

Krause, P., Boyle, D. P., and Base, F.: Comparison of different efficiency criteria for hydrological model assessment, Adv. Geosci., 5, 89-97, SRef-ID:1680-7359/adgeo/2005-5-89, 2005.

Lin, C. A., Vasiæ, V., Kilambi, A., Turner, B., and Zawadzki, I.: Precipitation forecast skill of numerical weather prediction models and radar nowcasts, Geophys. Res. Lett., 32 , L14801, doi:10.1029/2005GL023451, 2005.

Marchi, L., Borga, M., Preciso, M., Sangati, M., Gaume, E., Bain, V., Delrieu, G., Bonnifait, L., and Poganik, N.: Comprehensive post-event survey of a flash flood in Western Slovenia: observation strategy and lessons learned. Hydrol. Process. 23(26), 37613770, doi:10.1002/hyp.7542, 2009.

Montz, B. E. and Gruntfest, E.: Flash flood mitigation: recommendations for research and applications, Environ. Hazards 4, 15-22, 2002.

Nash, J. E. and Sutcliffe, J. V.: River flow forecasting through conceptual models, Part I - A discussion of principles, J. Hydrol., 10, 282-290, 1970.

Robic, M.: Investigating floods in the Selska Sora Valley, on 18 September 2007, with Hydrate international group, http://www. sos112.si/slo/tdocs/ujma/2008/111.pdf, 19.12.2008, Ujma, 22, 111-116, 2008 (in Slovenian).

Rodgers, J. L. and Nicewander, W. A.: Thirteen ways to look at the correlation coefficient, The American Statistician, 42, 59-66, doi:10.2307/2685263, 1988.
Rotach, M. W., Ambrosetti, P., Ament, F., Appenzeller, C., Arpagaus, M., Bauer, H. S., Behrendt, A., Bouttier, F., Buzzi, A., Corazza, M., Davolio, S., Denhard, M., Dorninger, M., Fontannaz, L., Frick, J., Fundel, F., Germann, U., Gorgas, T., Hegg, C., Hering, A., Keil, C., Liniger, M. A., Marsigli, C., McTaggart-Cowan, R., Montani, A., Mylne, K., Ranzi, R., Richard, E., Rossa, A., Santos-Muñoz, D., Schär, C., Seity, Y., Staudinger, M., Stoll, M., Volkert, H., Walser, A., Wang, Y., Werhahn, J., Wulfmeyer, V., and Zappa, M.: MAP DPHASE: Real-time Demonstration of Weather Forecast Quality in the Alpine Region, B. Am. Meteor. Soc., 90 (9), 1321-1336, doi:10.1175/2009BAMS2776.1, 2009.

Rusjan, S., Kobold, M., and Mikoš, M.: Characteristics of the extreme rainfall event and consequent flash floods in W Slovenia in September 2007, Nat. Hazards Earth Syst. Sci., 9, 947-956, doi:10.5194/nhess-9-947-2009, 2009.

Sharif, H. O., Yates, D., Roberts, R., and Mueller, C.: The Use of an Automated Nowcasting System to Forecast Flash Floods in an Urban Watershed, J. Hydrometeor., 7, 190-202, 2006.

Schmitz, G. H. and Cullmann, J.: PAI-OFF: A new proposal for online flood forecasting in flash flood prone catchments, J. Hydrol., 360, 1-14, doi:10.1016/j.jhydrol.2008.07.002, 2008.

Seibert, J.: Estimation of Parameter Uncertainty in the HBV Model, Nord. Hydrol., 28 (4/5), 1997, 247-262, 1997.

Strajnar, U.: Forecasting of Extreme Stationary Convection 18/9/2007 Zelezniki Flash Flood, http://ams.confex.com/ams/ pdfpapers/140913.pdf, last access: 24.7.2008, Extended Abstracts of the 13th Conference on Mountain Meteorology, 2008.

Szolgay, J.: Multilinear flood routing using variable traveletime discharge relationships on the Hron River, J. Hydrol. Hydromech., 52(2), 303-316, 2004.

Turner, B. J., Zawadzki, I., and Germann, U.: Predictability of precipitation from continental radar images. Part III: operational nowcasting implementation (MAPLE), J. Appl. Meteorol., 43(2), 231-248, 2004.

Webb, R. H. and Jarrett, R. D.: One-dimensional estimation techniques for discharges of paleofloods and historical floods, in: Ancient Floods, Modern Hazards: Principles and Applications of Paleoflood, edited by: House, P. K., Webb, R. H., Baker, V. R., and Levish, D. R., Water Sci. Appl. Series, 5, American Geophysical Union: Washington, D.C, 111-125, 2002.

Zanon, F., Borga, M., Zoccatelli, D., Marchi, L., Gaume E., Bonnifait, L., and Delrieu, G.: Hydrological analysis of a flash flood across a climatic and geologic gradient: the September 18, 2007 event in Western Slovenia, submitted, J. Hydrol., preprint provided after personal communication, 2010. 